\title{
Network, procedural and cognitive components of digital public governance implementation designs: The experience of European countries ${ }^{\star}$
}

\author{
A. V. Volkova, T. A. Kulakova \\ St. Petersburg State University, \\ 7-9, Universitetskaya nab., St. Petersburg, 199034, Russian Federation
}

For citation: Volkova A. V., Kulakova T. A. Network, procedural and cognitive components of digital public governance implementation designs: The experience of European countries. Vestnik of Saint Petersburg University. Philosophy and Conflict Studies, 2021, vol. 37, issue 1, pp. 118-135.

https://doi.org/10.21638/spbu17.2021.110

\begin{abstract}
The authors of the article aimed to study institutional designs for implementing digital public governance in the context of the problem of state governance. It was revealed that digital designs act as ways to ensure the implementation of the rules laid down in the system. They are focused on the development of communication skills, on preventing or minimizing conflicts in public policy, but do not exclude the risks of developing dysfunctions and serious contradictions. The article presents the results of a comparative study of the digitalization policy of European leaders in this area, Estonia and Germany, where there is a tendency to "slow down" innovations: uneven implementation of digital technologies in business and public governance, a wary attitude of citizens, a stable number of political and cultural attitudes and a focus more on regulation rather than coordination in Internet management. Contradictions between the network, procedural and cognitive components of digital public governance implementation designs appear. The authors believe that the gap with practically implemented technologies increases due to the existence of organizational and institutional barriers that need to be overcome in various ways (process, cognitive, etc.). Organizational barriers can be removed directly by state managers, while institutional barriers are the subject of policy initiatives. The novelty of the study lies in the recognition of the mobilization effect of "coercive digitalization". In the context of the pandemic, this mobilization was based on stable (stereotypical) interaction practices. According to the authors, as the forms of cooperation deepen, mutual long-term obligations become the main requirement and the state should create incentives for it. This is what prompts the demand for mutual responsibility of the digitalization "apostles", users and the state.
\end{abstract}

Keywords: digitalization, institutional designs, public policy, civil participation, conflicts, coordination, "smart regulation", ethics, trust, "coercive digitalization".

\section{Introduction. Articulation of the issue}

Nowadays the governability and efficiency of state systems, the quality of the economy, and the development of civil society are widely associated with the effectiveness of e-government, and the digitalization policy is a topic that has taken a leading position in

* The research was conducted with the financial support of the Russian Science Foundation, Project no. 19-18-00210 "Political ontology of digitalization: a study of the institutional basis of digital formats of state governability".

(C) St. Petersburg State University, 2021 
public discourse. The widespread use of digital technologies on the one hand, facilitates global trade, connects people through communication and enables faster data transfer, and on the other hand, creates many problems and conflicts such as data security issues, cybercrime or new foundations for inclusive development. Digital transformation can fundamentally change lives: communication processes become faster and easier, innovations create new jobs and bring improvements, for example, in the education sector, but at the same time, the institutional designs of digital public governance create opportunities for manipulation and distortion in public policy. The modern governmental system focuses on ensuring adaptability, mobility, flexibility, and sensitivity of all its elements, but still lacks the trust and support of citizens, whose involvement in the public sector is still relevant.

Institutional designs for the implementation of digital public governance as ways to ensure the implementation of the rules laid down in the system are focused on the development of communication skills and on preventing or minimizing conflicts, but nevertheless they do not exclude the development of contradictions and dysfunctions. "The metamorphosis of reducing objective risks inherent in society into subjective and individual risks, as well as reducing individual risks into objective and social risks through a complex system of relationships and interdependencies ends in conflict. In conflict, risk is objectified in actions that overwhelm the counteraction of negative prospects by establishing a system of relations in which the power of risk weakens and fades" [1].

Digitalization generates many new connections and meanings and is conceptually based on such principles as diversity, polemics, and conflict [2, p. 122]. Modern German researchers with the help of the combination of two related but still disparate areas of research, governance and Internet governance, have contributed to the understanding of this problem [3]. We should agree that Internet governance should be based on social coordination. The approach to governance presented by these authors focuses on processes (rather than structures), which makes it possible to define its boundaries as extremely dynamic (they are set and constantly discussed by communication participants). They see the difference between regulation and governance in the following: regulation implies deliberate procedures (resources, means and goals officially agreed upon) that can be achieved or unrealized, and governance is related to the conditions in which such activities are carried out. It is important to emphasize once again that governance here actually acts as a regime, a way of functioning of specific institutional structures [4]. This corresponds to the principles of neo-institutional analysis, which focuses not so much on formalized structures, but on the analysis of sustainable interaction practices.

It is noteworthy that increasing productivity in various areas (economy and education) through the introduction of digital technologies is accompanied by increasing electronic control and governance [5], and modern researchers point to threats to democratic values from the emerging "digital authoritarianism", which can exacerbate the crisis of democratic development in the world. At the present stage, the "building of a new ideal of civilizational development is fixed through the disclosure of a complex developing ethical system, where the inevitable component is a value conflict" [6, p. 105]. It is not by chance that the implementation of a digitalization policy, its regularities, features and risks, is an area of priority for modern Western European research [7], and most research projects are clearly interdisciplinary in nature. 
One of the most influential international indexes is the DESI index (Digital Economy and Society Index), which tracks the demand and supply of e-government services, as well as open data, thus helping to understand the specifics of implementation of the digitalization policy of each European country and general patterns in the European Union. The index offers an assessment of the following parameters, which are based on the ideology of the EU's digitalization policy:

- Communication, which is a necessary condition for the competitiveness of both states and individual regions (lands, communes, cities), makes the issue of measuring the quality of the deployed broadband network infrastructure a priority. Here we are talking about fast $(4 \mathrm{G})$ and ultra-fast $(5 \mathrm{G})$ communication technologies;

- Humanitarian (human) capital. Such concepts as "digital civic skills" and "digital talent", which convey the essence of a combination of various user skills and value priorities, have become firmly embedded in the economic and political discourse of Europeans;

- Citizens' level of consumption of Internet services. This indicator evaluates all types of online activity related to the process of consuming online content (online purchases and banking operations, downloading videos, music, games, and video calls);

- Integration of digital technologies into business. This indicator shows the degree, quality level of business digitization and effectiveness of e-commerce. The introduction of digital technologies for modern enterprises becomes a necessary condition for increasing efficiency, reducing costs and attracting customers and business partners. Nowadays the Internet is seen as a global sale point providing access to incomparably wider markets and new opportunities for growth;

- Digitalization of public services. This is an important indicator that reflects modern ideas about "good governance". The level of digitization of public services is assessed and the focus is on the development of e-government and e-health which is especially important in 2020.

After the evaluation of these indicators, it can be noted that the current European ideological attitude can be described as the following: the modernization and digitization of public services are presented as the main way to improve the efficiency of governance and the level of satisfaction of citizens. This is being conducted on the condition of the interest, competence and activity of both the state and citizens. By the end of 2019, online channels and procedures for $67 \%$ of Europeans have become a routine way of interacting with the state (compared to $57 \%$ in 2014), and these figures are likely to increase by the end of $2020^{1}$.

\section{Digital miracle in Estonia: a success story}

According to a number of international analyses, the compact former Soviet Republic of Estonia with a population of 1.3 million people surpassed a number of the largest EU economies (for example, Germany) in all indicators including the dynamics of digitaliza-

\footnotetext{
${ }^{1}$ DESI 2020. Available at: https://ec.europa.eu/digital-single-market/desi (accessed: 11.09.2020).
} 
tion implementation. In several indicators, Estonia was the best in the $\mathrm{EU}^{2}$. The levels at which the model is organized ("organizational, semantic, and technical") are somewhat different from those in Europe [8, p. 108]. Since Estonia is recognized as one of the world leaders in digitalization, this successful example of implementation of digitalization policies should be examined from an interdisciplinary perspective to determine the possibilities and limits of using "best practices" in European governmental systems and in the Russian Federation.

First of all, when we talk about Estonia's success we should mention the improvement of the country's standard of living which is closely linked to the development of the Estonian economy. The country began the post-Soviet period with economic subsidies and acute socio-political conflicts. Nowadays, the country demonstrates one of the highest growth rates of GDP in the EU - in 2019 it was $3.9 \%$. The Estonian economy has been able to achieve these indicators, and more importantly maintain positive dynamics of development, thanks to success in the construction, manufacturing, and transport sectors as well as to the intensive development of scientific activities and advanced technologies. The traditional agricultural sector (meat and milk production) and fishing for Baltic herring have lost their significance giving way to a high-tech economy. The country remains attractive for foreign investments and the international labor market. According to the Legatum Institute, the Republic of Estonia is among the world leaders in terms of quality and well-being of life. In the prosperity index of 175 world countries at the end of 2019, Estonia confidently was ranked $26^{\text {th }}$, exceeding EU members such as Slovakia, Poland, Czech Republic, Italy, Lithuania, Latvia, and in 2020 it moved up to the $21^{\text {st }}$ place 3 .

European experts note that Estonia has achieved the greatest success in the policy of empowering citizens' rights through digital technologies in the public sector. According to the Social Progress Index (a combined indicator of the international research project The Social Progress Imperative) which reflects the achievements of countries in terms of their social development, Estonia ranked $27^{\text {th }}$ among 100 countries in $2019^{4}$. The Social Progress Imperative project observes 54 basic human needs (freedom of choice, level of tolerance, etc.).

The policy of digitalization is perhaps the most important component of national success. The first breakthrough in digitization was made in 1995 when all schools in Estonia were connected to the Internet and new computer labs remained open after school to encourage free public use. In 1996 by the initiative and with the support of the President of Estonia Lennart Meri, the "Tiger Jump" program was started. The program aimed at familiarizing all students with computer technologies and Internet capabilities. State expenditures for the implementation of the program amounted to 35.5 million kroon, but each school was provided with a computer class and the training of IT-educated graduates began, which affected the overall level of IT-development in the country [9]. The country's policy, financial support from the EU and the mass distribution of personal gadgets have had significant results: in 2000 in Estonia $29 \%$ of the population used the Internet, compared to $91 \%$ in 2016.

${ }^{2}$ Available at: https://ec.europa.eu/digital-single-market/en/digital-public-services-scoreboard (accessed: 11.09.2020).

${ }^{3}$ Available at: https://www.prosperity.com/rankings (accessed: 11.09.2020).

${ }^{4}$ Available at: https://www.socialprogress.org/download (accessed: 11.09.2020). 
The problem of technically re-equipping state authorities became acute by 1996 (the shortage of computers at workplaces in the state structure was about 31.6\%) [10, p. 48]. The issue was recognized as a priority and in May 1998 the Parliament adopted the basic principles of an electronic space building which served as the basis for the formation of the Estonian information society. In 1998 the PeaTee network, also known as EEBone (a single network for all government institutions), was launched, and in 2000 a system of electronic government meetings was introduced: the system consisted of special software, servers, audio and video equipment, government documentation began to be saved in electronic form, organizational work (preparation of meetings, minutes, agendas, final decisions) was completely converted to electronic format and paperwork was stopped ${ }^{5}$. In 2001 this network evolved into X-Road (est. "X-Tee") - a technological platform created at the Tallinn University for the exchange of information for various branches of government through secure protocols [11]. This is how the foundation was built for the state portal which provided high efficiency of the procedural components of implementation designs in public governance.

Today, Estonian ministers remotely become acquainted with the list of issues for discussion, can quickly search for materials (all working documents are available in electronic form), express their point of view, and request additional information which corresponds to the principles of economy and environmental friendliness. The electronic format of meetings allows ministers to save time and increase the transparency of decisions. All documents related to the process of preparing governmental decisions (additions, corrections, comments) are available to all participants in the process in real time. Decisions made by the government are transmitted to journalists and all interested parties by email or via the Internet during the meeting.

Government meetings are usually held once a week. The open page of the information system contains a list of past and upcoming meetings with color markings (the agenda is highlighted in blue, the course of the meeting in orange, the meeting protocol in gray, etc.). After an agenda's approval, ministers express their agreement on the points and can indicate their wish to speak on a particular topic. For the optimization of work, it is important that if there is no comment to a topic on the agenda, this issue is no longer to be discussed at the meeting: it is considered as accepted.

There is no doubt that this format requires careful preparation which takes place in a digital format with the participation of the state chancellery. The meeting begins with the Prime Minister's review of the agenda. During the meeting, points in the information system are marked with a color code: the background color of the questions change, indicating that the issue is being discussed or has already been passed. The meeting protocol is confirmed and archived. This allows the official to find the meeting point by the keyword entered in the search bar. A package of information is stored in the archive for each issue. This can be the draft of a decision, an explanatory note, a list of approvals, and points of legal acts.

The majority of the Parliament's work is also conducted via the Internet. The parliamentary session can be observed on the Internet, on the electronic Internet page of the Parliament (online) ${ }^{6}$, and the transcript is published no later than the next day. The

${ }^{5}$ Riigikantselei. Available at: http://www.riigikantselei.ee/e_cabinet_ru/1_what_1_1.html (accessed: 21.12.2019).

${ }^{6}$ Available at: https://www.riigikogu.ee/ (accessed: 11.09.2020). 
Parliament's website provides an accurate schedule of sessions and opening hours so that anyone who wants to watch the broadcast of the meeting can also find the agenda, laws, various commissions, and everything that is directly related to the Parliament. All drafts of laws can be viewed through the electronic legislation system and their movement can be tracked through various stages. Any interested person can easily observe the creation of a law: Estonia initially relied on ensuring a high level of transparency in the public system $[8 ; 12]$, and on ensuring procedural fairness.

The method of data exchange used in state institutions was so convenient that its use was extended to other areas [13]. The main problem in organizing this system was to prevent data monocentricity, but Estonia was able to avoid this by using technologies that allow for the cross-use of multiple databases of different institutions through a single portal. The country has built an efficient, secure and transparent ecosystem in which $99 \%$ of public services are online $e^{7}$ and each new information system must be legally compatible with X-Road.

Portal Eesti.ee the website combines all the services provided by the state and is known to every citizen of the Republic of Estonia. It also contains detailed instructions on how to use the site. Eesti.ee is available in three languages - Estonian, English and Russian. This choice of languages can be explained by the fact that Estonian is the official language, Russian is the native language of $25.5 \%$ of the Estonian population ${ }^{8}$ and English is an international language. It should be recognized that today the amount of information provided in the three languages is not identical: most PDF documents (instructions, manuals) are in Estonian. The portal is also adapted for the visually impaired: a special menu has been created which allows for a convenient font, size and contrast of the displayed text to be chosen.

The key element of all innovations in Estonia is the ID card - an official identity document equivalent to a passport and driver's license. The ID card is a mandatory document for Estonian citizens ${ }^{9}$, is recognized by all EU countries, and it is the main mechanism for electronic communication between the state and society because by using an ID card you can use all e-services. The card has a high degree of protection due to the microsystem containing information not only about the owner but also about two certificates. One certificate is responsible for the identity of the card and the second contains the digital signature of the owner. You also need to know the PIN codes to use it. The first PIN is the code received with the ID card, and the second PIN is the owner's signature.

A digital identity card or Digi-ID is an analog of the electronic part of an ID card. The Digi-ID cannot be used as a visual identity document as it does not have a photo of the user. This card can identify the user in an electronic environment and insert a digital signature. Digi-ID and its certificates are valid for 3 years ${ }^{10}$. In addition to the ID card, from February 1, 2011 there is a mobile identification system - Mobiil-ID ${ }^{11}$ which is also a mobile analog of Digi-ID. It is provided by Estonian mobile operators. To use this service you need a special sim card which can be purchased from a mobile operator. Mobiil-ID is distributed only with special certificates that allow you to use e-services. You can use

\footnotetext{
${ }^{7}$ Available at: https://e-estonia.com/ (accessed: 03.09.2020).

${ }^{8}$ Available at: http://www.stat.ee/34267 (accessed: 23.04.2020).

${ }^{9}$ Available at: http://www.id.ee/?id=30977 (accessed: 23.04.2020).

${ }^{10}$ Available at: http://id.ee/?id=34635 (accessed: 23.04.2020).

${ }^{11}$ Available at: http://mobiil.id.ee/ (accessed: 23.04.2020).
} 
Mobiil-ID to send your digital signature. Mobiil-ID as well as the ID-card is protected by PIN codes. In order to be activated in one of the electronic systems or use e-services, it is enough to enter your phone number and somewhere else confirm the login using a PIN code that is directly entered from your mobile phone.

The entire list of e-services provided on the territory of the Republic of Estonia on the website eesti.ee. is divided into services for citizens, entrepreneurs, and public officials.

In the section "Services and Forms for Citizen", you can select from the list of national and local services as well as determine the target group (disabled person, pensioner, worker, adolescent, child) ${ }^{12}$. The "Citizen" section covers almost all areas (housing, education, transport, family, money and property, state defense, travel, state and citizen, consumer protection, health and healthcare... e-police services, etc.).

The "Education" subsection covers a wide range of opportunities capturing all levels of education - from applying for a place in kindergarten to enrolling in university. E-school (e-kool) can be considered one of the most widely used e-services throughout Estonia. It is aimed at teachers, students and their parents. Thanks to this service parents can monitor their children's progress and communicate with teachers directly on the Internet. Teachers can plan classes and post educational material, and students can receive homework and information about grades there. Moreover, next to the name of the subject there are envelopes which can be clicked on and opened that provide a window for messages to the teacher of the subject. The student can directly ask a question without leaving the house and without waiting for the next lesson. Thus, the system always allows students to be aware of the material covered and at the same time provides strict control over communication. Graduation certificates are issued in printed form, but they can also be viewed electronically.

Graduation certificates are accompanied by information about the curriculum and an assessment sheet. The target group of the service consists of graduates of the main and gymnasium levels of education since $2004^{13}$. Such a service as notification of the results of state exams is also popular. It allows everyone with the opportunity not to view the Internet portal periodically in the hope of seeing the results, but to find out about the results received directly at the moment of their publication. The notification is sent to the entered phone number and is a paid service.

The information system for admission to higher education institutions SAIS, which organizes the entire process of admission to higher education institutions, is very effective and easy to use. SAIS allows a graduate to submit an application for admission which automatically indicates the results of state exams and attestation marks. Then the university databases process the received applications and form lists based on the results of exams and attestation assessments; you can view your rating in the lists. SAIS also makes it possible to exchange information between the university and applicants, to confirm the application for a place of study or refuse it. At the end of study, all certificates are entered in the register. The certificate holder can view their qualification certificates at any time. Employers can also view certificates which minimizes acts of fraud.

The subsection "Health and Healthcare" allows to order a European health insurance card without leaving your home. This card entitles an Estonian citizen to receive medical

12 Available at: https://www.eesti.ee/est/teenused/kodanik (accessed: 15.05.2020).

13 Available at: https://www.eesti.ee/rus/uslugi/grazhdanin/haridus_ja_teadus/opilase_loputunnistused (accessed: 15.11.2019). 
care on equal terms with local residents for a temporary stay (from three months) in the European Union. You can write a letter to the University of Tartu clinic (one of the best clinics in Estonia) and know that this letter will not be ignored. Also, in this section you can apply for various compensation for treatment, view personal insurance data and data about the family doctor, make an appointment, or change the time, etc. Digital prescriptions are very popular among citizens: this service eliminates the possibility of losing a prescription, falsifying it or misusing it. You can view data about canceled prescriptions and prescriptions that have already been purchased. Also digital prescriptions allow the patient to find out at any time the expiration date of the prescription, instructions for use or see which doctors and pharmacists viewed their prescriptions. To get or buy medicine at a pharmacy you only need to show your ID card.

In the e-services section for entrepreneurs, you can find all the necessary information related directly to the business organization: various licenses, information about cargo transportation, archived data on work and seniority, tax returns and much more. Any entrepreneur can create a company via the Internet bypassing the red tape. This opportunity not only encourages entrepreneurs but also allows the state to monitor the processes taking place in the company. The site makes it possible to register a company in 18 minutes this means that in 18 minutes the company will be included in the register of companies, the tax department, etc. All you need is an ID card. The system can already recognize not only Estonian ID cards, but also Portuguese, Lithuanian, Finnish, etc., so that citizens of other countries can also use this service to organize their business in Estonia. To reduce the time spent on the search for various references, documents and applications, the official section has all the necessary links to information portals that may be needed ${ }^{14}$.

An important indicator of technological training and a high level of confidence in digital technologies is the process of implementing electronic voting. The first electronic elections in Estonia were introduced during local government elections in $2005^{15}$. If $1.9 \%$ of the population voted in 2005 , then 4 years later at next local elections this percentage increased to $15.8 \%$ of the total number of eligible voters. In $201124.3 \%$ of the population voted via the Internet in the parliamentary elections. To cast a vote via the Internet one can use an ID card or Mobiili-ID. After the card is identified, the personal data of the voter is removed which ensures that votes are anonymous. E-elections also enable citizens residing abroad to vote.

As in the rest of the world the main risks and conflicts in Estonia are related to the problems of impartial collection, processing, targeted use and confidentiality of personal data as well as data being manipulated. However, digital public services in Estonia are successfully positioned as fair, equal (accessible) and focused on the common good. Estonia positions its digital system as an effective way to overcome corruption and in this respect the country corresponds to the most important global trend [14, p. 84]. Finally, the foundation of e-Estonia-X-Road X-tee software, which provides a full range of services for citizens and a progressive security system, has the ability to expand new e-services and new platforms and to build an ecosystem and integrate with other systems (in 2018, the e-Federation of Estonia and Finland was created).

${ }^{14}$ Available at: https://joinup.ec.europa.eu/sites/default/files/inline-files/eGovernment\%20in\%20Estonia\%20-\%20February\%202016\%20-\%2018_00_v4_00.pdf (accessed: 11.09.2020).

${ }^{15}$ Vabariigi Valimiskomisjon Arhiv: Kohaliku omavalitsuse volikogu valimised 16. oktoober 2005. Available at: http://www.vvk.ee/varasemad/?v=k05/ (accessed: 15.05.2019). 
It is understandable why Estonia's success is often presented as a revolutionary digital project, "in fact, it is about a shared vision, inclusivity, justice and respect for individual rights" [15], which are at the heart of digital technology implementation activities. The components of the success of its digitalization policy are not only EU funding, a number of external challenges (the cyberattack of 2007) but also moral incentives. Digitalization of the state for the comfort of citizens in fact contains the notion of a national idea. Independence and the absence of a negative historical experience of statehood contributed to the exceptional confidence in the national government, which proposed a digital growth strategy and a state ideology based on innovative development. "Our digital society cannot work without trust between people, government agencies and private enterprises. Trust building has little to do with technical solutions, but it depends greatly on the worldview and culture. Changing this mindset is much more difficult and takes much more time than creating technical solutions", but overcoming this has emboldened the country's identity and culture and become its defining feature and also caused a record level of creativity and entrepreneurship (according to the Funderbeam trading platform, Estonia has 31 startups per 100.000 inhabitants, which is six times higher than the European average ${ }^{16}$ ).

Trust and justice, as it was proved by Jürgen Habermas, suggest the formation of a free public that controls the work of institutions from economic to political [16, p. 344], but despite the impressive prosperity, potential problems and possible crises of digital public policy are beginning to apper. Based on the Eurobarometer data, sociologist Aivar Voog identified three main problems in Estonia: the rise in the cost of living, the health situation and taxation ${ }^{17}$. In addition, the country is beginning to experience a shortage of workers and is currently attractive for migrant workers. The simplification of obtaining a residence permit and the influx of foreign labor can change the high indicators (including confidence in institutions) that have already been formed. In this case, the coherence of the network, process, and cognitive components of digital public governance implementation designs may be questioned.

\section{Digitalization in Germany: the deceleration logic}

Germany, which for decades has held leading positions in both political life and the economy of the European Union and clearly claims to be an absolute leader in technical and technological issues, faced the problem of "delay" in institutionalization of digital technologies implementation [17; 18]. European studies show that Germany is lagging behind in a number of parameters that are fundamental for the quality of digital transformation: business participation and involvement, the level of digital technologies, the quality of e-government, digital skills of citizens, their trust in digitalization policies and structures.

The history of creating the framework conditions for digitalization in Germany is a systematic and phased implementation of a number of programs and digital strategies which has been in progress for more than fifteen years. The most significant processes for institutionalizing the introduction of digital technologies are the implementations of fed-

${ }^{16}$ Available at: https://www.raconteur.net/technology/public-sector-technology-2018/estonia-digitalsociety (accessed: 11.09.2020).

${ }_{17}$ Available at: https://rus.err.ee/912213/opros-glavnye-problemy-v-jestonii-udorozhanie-zhizni-zdravoohranenie-i-nalogooblozhenie (accessed: 11.09.2020). 
eral programs such as "BundOnline 2005" 18 which assumed the transfer of about 350 public services to an online format by 2005 . The goal of this program was to implement appropriate IT-infrastructures, requirements, and standards. Services were evaluated by the size of the user segment, advantages, resource-saving potential, strategic advantages and synergistic potential. A gap in the processes of institutionalization of digital technologies in business and public governance has emerged due to this program. Considerable attention was paid to the development of an appropriate legal framework, data security and confidentiality which are traditionally important elements in the mentality of German society. This bureaucratic approach to digitalization was driven by cultural stereotypes and has not lost its relevance to this day.

The federal governmental ICT strategy "Digital Germany 2015" and the program "Digital Governance 2020" were consistently discussed and implemented. The most relevant today is the "Strategy of Future 'Gigabit Germany"'19 planned for 2025, which focus on the creation of network infrastructure. Implementation of the digitalization policy in Germany has been linked to the Internet of things, autonomous driving and Industry 4.0 which requires:

- Technical re-equipment (availability of broadband connection, fiber-optic network);

- Creation of a regulatory framework to expand opportunities for investments and innovations, which corresponds to the cultural traditions and spirit of the "Weber bureaucracy";

- Strength of data security and development of information autonomy. Nowadays, security is the main public value formed during the implementation of the digitalization policy, and in Germany the "capture" of public policy processes by artificial intelligence, the implementation of algorithms and the expansion of the influence of "machines" are considered as potential threats to democracy and its institutions;

- The promotion of "smart networks" in key business infrastructure;

- The formation and development of "digital skills" or "digital talent" of citizens, understood as the sum of skills and orientations, including user skills, adaptability, creative thinking, conflict-free and commitment to humanitarian values.

The institutionalization of digital technologies is the subject of research and development by a number of research centers including the Einstein Center Digital Future, Weizenbaum-Institut für die vernetzte Gesellschaft - Das Deutsche Internet-Institut (German Internet Institute), and Fraunhofer-Leistungszentrum "Digitale Vernetzung" ("Digital Association"). All of them are engaged in the development of concepts and implementation of digitalization policies and resource (potential) of Germany in this area.

18 BundOnline 2005. Umsetzungsplan für die eGovernment-Initiative. Bundesministerium des Inneren (BMI), Berlin: Stabstelle Moderner Staat - Moderne Verwaltung. Available at: https://www.verwaltung-innovativ.de/SharedDocs/Publikationen/Bestellservice/fehlt_zweites_pdf_bundOnline_2005_ umsetzungsplan_f\%C3\%BCr_die_egovernment.pdf?_blob=publicationFile\&v=1 (accessed: 10.08.2020).

${ }_{19}$ Zukunftsoffensive Gigabit-Deutschland. Offensive der Netzallianz zum Ausbau gigabitfähiger konvergenter Netze bis 2025. 07.03.2017. Available at: http://www.bmvi.de/SharedDocs/DE/Publikationen/DG/ netzallianz-digitales-deutschland.pdf?__blob=publicationFile (accessed: 10.08.2020). 
They can be considered practically the most significant in the European Union and surpass the capabilities of Estonia.

The low "effectiveness of the implementation of the federal government's plans in the field of digitalization is largely due to confusion in the distribution of powers in this area" [19, p. 160; 20]. Today in Germany 244 teams in 76 departments of 14 ministries are responsible for digitalization processes. The most active actors are the Federal Ministry of Economy and Energy (industrial digitalization, digital platforms and economic networking), the Ministry of the Internal Affairs (information technology policy, IT and cybersecurity), the Ministry of Transport (digital infrastructure), and the Ministry of Education and Science (digital education and information society issues). The issues of the coordination center have not been resolved in 2019 and the pandemic shifted priorities and made its own adjustments to public policy processes.

According to the results of the "Digital report 2020" of the Allensbach Institute (Das Institut Demoskopie Allensbach - the largest center for public opinion research in Germany), the problem of trust is quite acute. Citizens' confidence in the competence of structures in the field of digitalization was evaluated separately for large economic actors (large firms and enterprises) and government structures directly. As we can see, the gap in the processes of institutionalization of digital technologies in business and public governance which was outlined in "BundOnline 2005 " is still an obvious problem in German society and public policy.

The majority of German citizens believe that the federal government does not have enough understanding of real processes and problems in order to implement digital technologies: only $2 \%$ of the population consider the government as sufficiently competent in this area, $47 \%$ of respondents for the "Digital report 2020 " consider the government to be "little competent", and $10 \%$ believe that it is "not at all competent".

At the same time in terms of firms and large companies, $70 \%$ of respondents expressed confidence that they are using digitalization processes correctly.

The survey also illustrated that the term "digitalization" does not have a uniform definition among citizens. Digitalization is understood as a variety of processes and phenomena: the conversion of analog content or processes into digital form, the expansion of broadband access and mobile phone coverage, the principles of preparing students for remote working conditions or working in social networks ${ }^{20}$. The improvement of the cognitive components of digital designs and their perception are being studied in sufficient detail.

The concern of German specialists is reflected in the problems of numerous research projects. In 2019, the International school of management (ISM) in collaboration with the digital services division $(\mathrm{PwC})$ studied the needs, fears and expectations of the German population in regard to the "megatrend of digitalization". Changes in the configuration of social life and the prospects of artificial intelligence (AI) were highlighted as the most significant trends of the future. Electronic payment was the third most important. Common to respondents of all ages was the expectation that companies offered simple and standardized payment methods. Most of the changes are related to big data, AI, and autonomous driving. According to the study, all age groups in general perceive the trend for digitization as a great opportunity to facilitate and speed up processes, but there is a need for

${ }^{20}$ Die Bundesregierung bekommt den digitalen Wandel nicht hin. Available at: https://www.faz.net/ aktuell/wirtschaft/digitec/digitalisierung-regierung-bekommt-digitalen-wandel-nicht-hin-16572685.html (accessed: 10.08.2020). 
greater transparency and control over stored personal data. German citizens are sure that digitization strongly affects their personal lives, provokes an overload of information and intensive "fast" communication leads to a high level of stress. They are perceived as factors that reduce the importance of the transmitted content. Digitization of the work sphere creates new jobs and opportunities, but it also requires skills, flexibility and adaptability. Improving the quality of work processes has increased people's dependence on technology and resulted in new efforts and challenges. Digital identification (digital medical records in healthcare) raises questions about what data is stored, where and for what purposes.

Thus, the perception of digitalization in German society is closely linked to concerns. Citizens expect from companies, governments, and legal systems guarantees of their safe$t^{21}$. The aggravation of conflicts related to the problems of the population's literacy level and the traditional contradictions of German society was clearly confirmed in the spring of 2020 in Berlin, when the artist Simon Weckert used 99 smartphones to trick Google Maps algorithms and create traffic jams in order to warn the public about the dangers of manipulative practices in a digital society ${ }^{22}$.

The website of E-government and federal administration Bund.de is a gateway to the services and online information of the German federal administration and other governmental agencies ${ }^{23}$. At the federal level you can digitalize your passport (a plastic card with its own number $)^{24}$ on the portal, you can issue an Elterngeld (the amount that is paid for the birth of a child), and receive a driving license. All the main tasks are performed at the city level which determines the fragmented and even chaotic nature of the digitalization policy, the contradictions between the components of institutional designs for implementing digital public governance.

The history of digitalization policy implementation is quite diverse and it reflects all the main trends and conflicts. The problem is that there is currently no alternative to highfrequency data networks such as $5 \mathrm{G}$ for connection of high-performance computers wirelessly and in real time, which is necessary for the mass distribution of "smart technologies". There is not a regular network everywhere in Germany and the digitalization is determined by the conditions of a particular land. Bavaria which claims to be a leader in implementing digitalization policies (the Munich Digitalization Plan) ${ }^{25}$ has launched a project to collect concrete data on digitization success stories for the 8th Open Governmental Day 2020, under the motto "best practices in digitalization: share experience - learn together".

In the Eastern area technological innovations are not so large-scale, but in 2020 the Parliament of Mecklenburg-Western Pomerania achieved success in finalizing the law on e-government which establishes the obligation of the federal government, lands and local authorities to provide their services in electronic format no later than January 1, 2023 through administrative portals linked to existing institutions ${ }^{26}$. One of the main tasks of

21 Available at: https://www.pwc.de/de/digitale-transformation/studie-digitalisierung-in-deutschland. html status-quo (accessed: 11.09.2020).

22 Available at: http://www.simonweckert.com/googlemapshacks.html (accessed: 10.08.2020).

23 Available at: https://www.service.bund.de/Content/DE/Home/homepage_node.html (accessed: 11.09.2020).

24 Available at: https://www.personalausweisportal.de/SharedDocs/kurzmeldungen/Webs/PA/EN/ buehne_meldung.html (accessed: 11.08.2020).

${ }^{25}$ Die Digitalisierungsstrategie Münchens | München-Digital-Portal. Available at: https://muenchen. digital/ (accessed: 11.08.2020).

26 Available at: https://www.regierung-mv.de/ (accessed: 01.08.2020). 
the revision of the law was to digitalize the procedure for verifying identity by signing and presenting a personal identity card. The new law on e-government will create the necessary legal framework for this which is expected this year ${ }^{27}$.

The presence of such conflicts makes it necessary to address the institutional capabilities of ethics. Since 2017 Darmstadt has been working to codify ethical principles for the digitalization process. The Ethics and Technology Advisory Council (a fully citizencontrolled initiative in the city's governance structure) has supported almost 100 digitalization projects in two years and provided administrative and coordination support for complex cases. Its institutional design is defined by values such as volunteerism, trust and openness. By the admission of project participants, the need to discuss and coordinate the ethical framework for implementing digitalization has arisen due to the participation of citizens and working meetings of heads of various departments and authorities. With the involvement of external and internal consultants, 14 areas of activity were identified in which individual and intersectoral digitalization projects were to be implemented ${ }^{28}$.

There are ethical problems of the "Internet of things" in the spotlight: mass digitalization is possible in the case of IOT (Internet of Things) network that could connect objects to each other. Creating such a network is already technically quite a complex task which also has a "bad aftertaste" ("smart" is initially interpreted very individually: if everyday subjective actions and needs are satisfied faster, then the situation is perceived as "smart", implying that it is better than before). But such a system needs to be implemented not only in the work life but also in the personal one. In other words, invading the personal space of citizens.

The Darmstadt public recognizes that the highest goal of all digitalization projects is to make everyday life more enjoyable, productive and environmentally friendly for everyone while achieving key goals of the community. "Ethical recommendations for the development of Darmstadt into a digital city" adopted by the decision of the Advisory Board in June 2019 are perceived by developers as a proposal for all of Germany:

- Commitment to the common good. The digitization process should be oriented towards the common good. The goal of digital transformation should always be the social and / or environmental improvement of public services of common interest and other urban services. This should be done as economically and efficiently as possible;

- Democratic control. The task, development, implementation and use of digitization projects should have self-government controlled by the Parliament in accordance with applicable/existing rules. This also applies to companies that the city participates in. There should be no new power structures that evade democratic control and pose a threat to people's fundamental rights, security and privacy;

- Responsibility and transparency. The responsibility of democratically elected bodies for decisions in the city must be preserved. Automated procedures should not replace them. It is necessary to disclose the criteria for automated administrative actions. When a city communicates with its citizens, it is necessary to make it clear from the very beginning which medium is being used;

${ }^{27}$ Available at: https://www.regierung-mv.de/Landesregierung/em/Ministerium/Rechtsvorschriften/ (accessed: 05.08.2020).

${ }^{28}$ Available at: https://www.digitalstadt-darmstadt.de/digitalstadt-darmstadt/beiraete/ (accessed: 05.09.2020). 
- Discrimination and unhindered access to services. The availability and usability of analog services or related analog assistance offers should be maintained to ensure participation in public life of all groups of the urban population;

- Sovereignty of the city and its citizens. The public sector and citizens must be able to develop, operate and use digital infrastructures, platforms and basic services with confidence. Dependence on products and companies should be avoided.

In addition, the issues of data openness which represent a democratically resolved and legitimate interest to the public and data protection (personal data must be recorded and transmitted as rarely as possible and cannot be sold) are taken into account.

All digitization projects should offer current and future generations equal development opportunities. All digital city projects must take into account the vulnerability of public service systems and guarantee their functional reliability (cybersecurity) ${ }^{29}$.

Without detracting from the importance of discussing the ethical aspect of digitalization policy, it should be recognized that these principles are more focused on regulation than coordination. Modern Germans are concerned about the sustainability of digitalization policies, the potential risks of usurpation of power by "new power structures" or "automated processes", inclusivity (not excluding from the system those, due to their social/ financial status, cannot fully be a member of the digital society), the risk of dependence on certain products and large companies, personal data protection and "digital hygiene".

As we move towards long-term, basic, social transformations as the range of available objective information technologies increases, the gap with practically implemented technologies increases due to the existence of organizational and institutional barriers that need to be overcome in various ways (process, cognitive, etc.). If organizational barriers can be eliminated directly by governmental managers, then institutional barriers can be the subject of political initiatives $[21 ; 22]$.

The digital revolution creates jobs and we can expect a significant increase in staff productivity and efficiency, but at the same time the demands on companies are growing. In calling for innovations, reformers often forget about their negative consequences [5, p. 216]. As the forms of cooperation deepen, mutual long-term obligations become the main requirement and incentives must be created. This is what causes the demand for mutual responsibility of the "apostles" of digitalization, users and the state. Even those who grew up in the digital world - the so-called "digital natives" - begin to consciously resist the dominance of digital technologies and from time-to-time exclude the Internet from their lives.

\section{COVID-19 as a trigger for coercive digitalization: challenges for public policy}

Today, a successful winning strategy from the current pandemic (which is considered not just a catalyst, but a trigger for digitalization) is directly related to the reliability of digital public services, including e-health (services that track the spread of infection, receive electronic prescriptions, exchange medical data), and the use of advanced technologies to improve public services for the stability of communication channels.

${ }^{29}$ Die Beiräte der Digitalstadt Darmstadt. Available at: https://www.digitalstadt-darmstadt.de/digitalstadt-darmstadt/beiraete/ (accessed: 05.09.2020). 
Germany was acutely aware of the spread of the COVID-19 virus and required strict restrictions from the state. The speeches of world leaders at the beginning of the pandemic in the spring of 2020 contained general guidelines, among which the main idea was a request for trust in the national government, the idea of solidarity and cohesion in the face of difficulties. It should be noted that for Angela Merkel the idea of preserving democracy was at the center of her appeal, and the virus was also positioned as a political challenge.

By the middle of 2020 in the German discourse, the term "coercive digitalization" was formed: citizens with limited movement were forced to master new technologies, communication opportunities of computers and personal gadgets, which gave rise to many acute issues from the problems of inclusive development to the formation of new mental attitudes. It is noteworthy and important that the pandemic is perceived in Germany as a challenge both for public governance and civil society. An important point to consider and adopt is the idea that the pandemic has irrevocably changed public life - the world will never be the same, and now a "new norm" for public life is being formed which has already determined the processes of public policy during the "second wave" of the crisis in the fall of 2020, perhaps not the last one.

Germany offers a number of these norms, many of which are relevant and universal ${ }^{30}$ :

- The crisis forces many companies and citizens to save money. Life has become more modest, the "consumer society", which has been actively criticized in recent years, is forced to change its priorities and values. Digitalization has always been a catalyst for greater efficiency and financial stability, but the pandemic has strengthened such effects;

- The issue of ecological development in the context of a pandemic is also interesting. The decrease in industrial activity, reducing car traffic and a sharp decline in the number of flights, and as a consequence of the reduction of emissions and improvement of the ecological situation in technically developed regions, actualized the issue of clean energy;

- Adoption of digital collaboration. Travel-activity has rapidly changed around the world which is impressive. After the acute phase of this crisis the question about the need for travel, especially in light of the new sustainable reality which overrides the competitiveness and thus economic survival, is likely to be more often emphasized;

- Development of hybrid working models;

- Video conferencing, e-learning and digital work will become more commonplace in terms of this "new normal", which means developing digital skills for productive work from home and providing motivation for employees, despite the reduction in social interaction;

- Use of the digital education potential. The experience of 2020 has shown that it is impossible to completely replace traditional classroom learning with home-based learning. Not only because of the quality of the material provided, but also to a greater extent because of the loss of social learning skills and teamwork of students. However, the experience of the COVID crisis has clearly shown that digital education is not only feasible but also extremely sensible. By the beginning of

${ }^{30}$ Available at: https://www.telekom.com/en/careers/our-focus-topics/center-for-strategic-projects/trafotalk/impact-of-covid-19-corona-as-a-catalyst-for-digitalization-part-3--601542 (accessed: 11.09.2020). 
2020, the "digital school" was a rarity in Germany. On the one hand, the pandemic exposed the digital deficit of the German education system, on the other hand, it brought this topic to the top of the agenda. For example, the city of Cologne at the end of May 2020 was able to mobilize budget resources and launched a program to provide students with 27,000 additional digital devices (tablet computers).

The pandemic has changed social life by giving it a "digital boost". The rejection of major sporting events on a global and regional scale, the fading and transformation of cultural life and the need to abandon the usual family celebrations and the usual communication of friends and colleagues pose a threat to the social climate and social well-being. But it also encourages new, innovative and unexpected forms of interaction (concerts on balconies, online performances and family celebrations). Currently, broad segments of society are using FaceTime and Skype communication technologies to expand opportunities for participation in digital social life. Among the positive examples is the grassroots organization of mutual aid networks (students, teachers, doctors...) which demonstrates the actualization of personal responsibility and values such as solidarity and mutual assistance (a web-source where teachers collect tips for each other on how to conduct lessons in times of distance learning and "coercive digitalization") ${ }^{31}$. Civil science projects have gained a new impetus for development. The platform "Citizens create knowledge" (Die Plattform für Citizen Science | Buerger schaffen Wissen), a project of the Technical University of Munich, is aimed at attracting ordinary people to science ${ }^{32}$. These resources stimulate the growth of civic engagement, civic cooperation and responsibility and they also contribute to the development of "digital talents" and "digital abilities". Active development and support of this direction in modern Germany is connected with the desire of the government, business and society to achieve social progress even in the face of a pandemic.

In conclusion, it can be stated that "coercive digitalization" has a mobilization effect, but it is based in each state on stable stereotypical practices of interaction. The main idea of the "new reality", which is relevant for European states, consists of the following: the movement from an undesirable stress test to an accelerator of digitalization in all spheres of life from the economy to education and private life.

Thus, the success of the implementation of the digitalization policy depends on the development of a state system and non-state entities that use common norms and values which interact with each other on the basis of resource interdependence in order to achieve a common agreement, the public good [10]. Such networks are now recognized as the most effective form of communication between the state and civil society, they stimulate the permanent development of innovative solutions, the search for new communication channels and social learning. In the process of institutionalization of digital innovations, when the exchange of knowledge and technologies becomes vital for the development of each company, industry and national economies, pluralization makes rigid regulation ineffective. As a result, a policy is formed to a greater extent to ensure coordination based on common ethical principles and values rather than regulation of the management of knowledge and socio-information processes.

${ }^{31}$ Available at: https://hochschuldidaktik-online.de (accessed: 11.09.2020).

32 Available at: https://www.mcts.tum.de/research/evidenz -in-der-civil-science/ (accessed: 11.09.2020). 


\section{References}

1. Strebkov, A. I. and Musaev, A. I. (2020), Risk of power - power of risk, Vestnik SPbGU. Ser. Filosofiia i konfliktologiia, vol. 36, no. 2, pp. 394-406. https://doi.org/10.21638/spbu17.2020.215. (In Russian)

2. Smorgunov, L. V. (2020), Ontological turns, Sotsial'nye i gumanitarnye znaniia, vol. 6, no. 2, pp. 122133. (In Russian)

3. Ziewitz, M. and Pentzold, C. (2014), In search of internet governance: performing order in digitally networked environments, New Media \& Society, vol. 16, no. 2, pp. 306-322.

4. Hofmann, J., Katzenbach, C. and Gollatz, K. (2017), Between coordination and regulation: Finding the governance in Internet governance, New media \& Society, vol. 19, iss. 9, pp. 1406-1423, https://doi. org/10.1177/1461444816639975.

5. Dudnik, S.I. and Markov, B.V. (2020), The education crisis in the digital age, Vestnik SPbGU. Ser. Filosofiia i konfliktologiia, vol. 36, no. 2, pp. 214-226, https://doi.org/10.21638/spbu17.2020.201. (In Russian)

6. Danilov, A.N. (2020), Return of the dictatorship: a new reading of modernity, Vestnik SPbGU. Ser. Filosofiia i konfliktologiia, vol. 36, no. 1, pp. 105-115, https://doi.org/10.21638/spbu17.2020.109. (In Russian)

7. Smorgunov, L. V. (2019), Institutionalization of governability and the problem of veillance in the space of digital communications, Iuzhno-rossiiskii zhurnal sotsial'nykh nauk, vol. 20, no. 3, pp. 62-75. (In Russian)

8. Toom, Ya. and Komleva, V.V. (2020), Evolution of the public administration system. The Republic of Estonia, Gosudarstvennaya sluzhba, no. 4, pp. 82-118. (In Russian)

9. Shvaikovskii, O., Kil'p, A. and Vimberg, I. (2020), E-Estonia. The country where the Internet lives. Available at: https://es.slideshare.net/priimagi/estonia-egovernance-leaflet-in-russian-of-2010 (accessed: 12.04.2020).

10. Odrats, I. (2002), Information technology in public administration of Estonia, Tallinn: Estonian Informatics Centre Press.

11. Ivaneiko, S. (2020), Electronic citizenship and zero bureaucracy: how Estonia became an IT country. Available at: https://tech.onliner.by/2020/10/12/kak-estoniya-stala-it-stranoj (accessed: 12.04.2020).

12. E-Estonia: the digital society (2011), Tallinn: Velvet.

13. Tiits, M. and Rebane, K. (2009), Eesti infotehnoloogia tulevikuvahed, Tallinn: Eesti arengufond Press.

14. Koulakova, T.A. and Volkova, A.V. (2019), Ethical dimensions of anticorruption policy, Vestnik SPbGU. Ser. Filosofiia i konfliktologiia, vol. 35, no. 2, pp. 336-348.

15. Silaskova, J. and Takashi, M. (2020), Estonia built one of the world's most advanced digital societies. During COVID-19, that became a lifeline. Available at: https://www.weforum.org/agenda/2020/07/estoniaadvanced-digital-society-here-s-how-that-helped-it-during-covid-19/ (accessed 12.04.2020).

16. Habermas, Jü. (2016), The Structural Transformation of the Public Sphere: An Inquiry into a Category of Bourgeois Society, Moscow: Ves' mir Publ. (In Russian)

17. Akkaya, C. and Krcmar, H. (2019), Potential Use of Digital Assistants by Governments for Citizen Services: The Case of Germany, in Proceedings of the $20^{\text {th }}$ Annual International Conference on Digital Government Research, June, pp. 81-90, https://doi.org/10.1145/3325112.3325241.

18. Fleischer, B. and Rother, Y. (2016), Germany: The path to open data leadership, in Digital Government: Leveraging Innovation to Improve Public Sector Performance and Outcomes for Citizens, 1 January, pp. 169-189, https://doi.org/10.1007/978-3-319-38795-6_9.

19. Supyan, N. V. (2018), Digital goals of the grand coalition, Nauchno-analiticheskii vestnik IE RAN, no. 2, pp. 159-167. (In Russian)

20. Safiulin, A. R. (2017), Industry 4.0 and the development priorities of the economy and society in Germany, Bulletin of UlSTU, no. 3, pp. 69-72. (In Russian)

21. Schedler, K., Guenduez, A. and Frischknecht, R. (2019), How smart can government be? Exploring barriers to the adoption of smart government, Information Polity, vol. 24, no. 1, pp. 3-20.

22. Schou, J. and Hjelholt, M. (2018), Digitalization and public sector transformations, https://doi.org 10.1007/978-3-319-76291-3.

Received: May 17, 2020

Accepted: December 29, 2020

Authors'information:

Anna V.Volkova - Dr. Sci. in Political Science, Professor; a.volkova@spbu.ru

Tatyana A. Kulakova - Dr. Sci. in Political Science, Professor; koulakova812@mail.ru 


\title{
Сетевые, процессуальные и когнитивные компоненты дизайнов внедрения цифрового публичного управления: опыт европейских государств
}

\author{
А. В. Волкова, Т. А. Кулакова \\ Санкт-Петербургский государственный университет, \\ Российская Федерация, 199034, Санкт-Петербург, Университетская наб., 7-9
}

Для цитирования: Volkova A. V., Kulakova T. A. Network, procedural and cognitive components of digital public governance implementation designs: The experience of European countries // Вестник Санкт-Петербургского университета. Философия и конфликтология. 2021. Т. 37. Вып. 1. C. 118-135. https://doi.org/10.21638/spbu17.2021.110

Авторы статьи ставили своей целью исследование институциональных дизайнов внедрения цифрового публичного управления в контексте проблемы государственной управляемости. Выявлено, что цифровые дизайны выступают как способы обеспечения реализации заложенных в систему правил, они ориентированы на развитие коммуникативных способностей, предупреждение или минимизацию конфликтов в публичной политике, но не исключают риски развития дисфункций и серьезных противоречий. В статье представлены результаты сравнительного исследования политики цифровизации европейских лидеров этого направления - Эстонии и Германии, где прослеживается тенденция к «торможению» инноваций: неравномерное внедрение цифровых технологий в бизнесе и государственном управлении, настороженное отношение граждан, устойчивость ряда политико-культурных установок и ориентация в большей степени на регулирование, а не на обеспечение координации в управлении Интернетом. Возникают противоречия между сетевыми, процессуальными и когнитивными компонентами дизайнов внедрения цифрового публичного управления. Авторы исходят из того, что по мере расширения диапазона доступных объективных информационных технологий разрыв с практически реализуемыми технологиями увеличивается за счет существования организационных и институциональных барьеров, которые необходимо преодолевать различными способами (процессными, когнитивными и др.). Организационные барьеры могут быть устранены государственными менеджерами напрямую, институциональные - являются предметом политических инициатив. Новизна исследования состоит в признании мобилизационного эффекта «вынужденной цифровизации», притом что в условиях пандемии эта мобилизация основывалась на устойчивых (стереотипных) практиках взаимодействия. По мнению авторов, по мере того как формы сотрудничества углубляются, взаимные долгосрочные обязательства становятся основным запросом, и для этого государством должны быть созданы стимулы. Именно это вызывает требование взаимной ответственности «апостолов» цифровизации, пользователей и государства.

Ключевые слова: цифровизация, институциональные дизайны, публичная политика, гражданское участие, конфликты, координация, «умное регулирование», этика, доверие, «вынужденная цифровизация».

Статья поступила в редакцию 17 мая 2020 г;; рекомендована в печать 29 декабря 2020 г.

Контактная информация:

Волкова Анна Владимировна - д-р полит. наук, проф.; a.volkova@spbu.ru Кулакова Татьяна Александровна - д-р полит. наук, проф.; koulakova812@mail.ru

* Исследование выполнено при финансовой поддержке РНФ, проект № 19-18-00210 «Политическая онтология цифровизации: исследование институциональных оснований цифровых форматов государственной управляемости». 